\title{
Cold temperature tolerance of the alien Indo-Pacific damselfish Neopomacentrus cyanomos from the Southern Gulf of Mexico
}

\author{
Nelly Tremblay a,c,1, Edlin J. Guerra-Castrob,c, Fernando Díaz ${ }^{\mathrm{d}}$, Gabriela Rodríguez-Fuentes ${ }^{\mathrm{c}, \mathrm{e}}$, \\ Nuno Simões ${ }^{\mathrm{a}, \mathrm{c}, \mathrm{f}}$, D. Ross Robertson ${ }^{\mathrm{g}}$, Carlos Rosas ${ }^{\mathrm{a}, \mathrm{c}, *}$ \\ ${ }^{\text {a } U n i d a d ~ M u l t i d i s c i p l i n a r i a ~ d e ~ D o c e n c i a ~ e ~ I n v e s t i g a c i o ́ n, ~ F a c u l t a d ~ d e ~ C i e n c i a s, ~ U n i v e r s i d a d ~ N a c i o n a l ~ A u t o ́ n o m a ~ d e ~ M e ́ x i c o, ~ S i s a l, ~ Y u c a t a ́ n, ~ M e x i c o ~}$

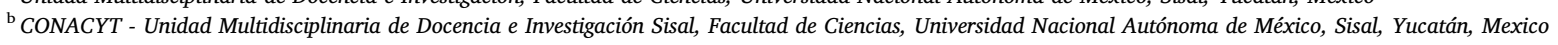 \\ ${ }^{\mathrm{c}}$ Laboratorio de Resilencia Costera (LANRESC, CONACYT), Sisal, Yucatán, Mexico \\ ${ }^{\mathrm{d}}$ Laboratorio de Ecofisiología de Organismos Acuáticos, Departamento de Biotecnología Marina, Centro de Investigación Científica y de Educación Superior de Ensenada, \\ Ensenada, Baja California, Mexico \\ e Unidad de Química Sisal, Facultad de Química, Universidad Nacional Autónoma de México, Puerto de abrigo s/n, Sisal, Yucatán, Mexico \\ ${ }_{\mathrm{f}}^{\mathrm{f}}$ International Chair for Coastal and Marine Studies in Mexico, Harte Research Institute for Gulf of Mexico Studies, Texas A\&M University-Corpus Christi, United States of \\ America \\ ${ }^{\mathrm{g}}$ Smithsonian Tropical Research Institute, Balboa, Panamá
}

A R T I C L E I N F O

\section{Keywords:}

Routine metabolic rate

Sea temperature

Offshore oil platforms

Invasive species

Metabolites

Cellular stress markers

\begin{abstract}
A B S T R A C T
The abundance of the alien, Indo-Pacific damselfish Neopomacentrus cyanomos on an oil-loading platform in the southwest Gulf of Mexico indicates that widely distributed platforms could facilitate the expansion of its geographic range across the western and northern fringes of the Gulf. From there it likely will spread to other areas of the Greater Caribbean. The lionfish example demonstrates that it eventually happens, and can do so rapidly. Reduced temperature effects on the physiology of this species were examined to better predict its survivability in the northern Gulf during winter, when sea surface temperatures fall as low as $15^{\circ} \mathrm{C}$ along the coast. Overall, our results show that when the degree of experimental temperature decline was large and rapid, no compensation occurred and the stress response observed mostly reflected cellular processes that minimized damage. Integrated biomarker response values were significantly different between fish rapidly exposed to colder $v$ s. warmer temperatures (declines of $-4^{\circ} \mathrm{C}$ each day, from 26 to $14{ }^{\circ} \mathrm{C}$ ), reflected in higher values of blood metabolites and routine metabolic rates observed in fish exposed to 14 and $18^{\circ} \mathrm{C}$ respectively, and lower activity of all enzymes, lower protein carbonylation, and higher oxidative damage to lipids in fish exposed to $14^{\circ} \mathrm{C}$. While the physiological proxies responded to minimize damage during the rapid-decrease experiment, the same proxies reflected the consequences of compensation when fish were thermally challenged after a 45 days acclimation at $18^{\circ} \mathrm{C}$. In this case, lower values of blood metabolites and high antioxidant levels and indicators of damages underpinned its pejus lower range. Based on the results of the present work, it seems clear that low winter SSTs in the northern Gulf will slow down the colonization of the inshore area of $N$. cyanomos. We suggest that the use of physiological cellular stress markers on specimens acquired at the beginning of an invasion should be implemented in new standardized experimental protocols, including both rapid increases/decreases of temperature and post-acclimation temperature challenges, to assess the invasiveness potential of aquatic species such as this.
\end{abstract}

\section{Introduction}

Neopomacentrus cyanomos, a species native to the Indo-west Pacific Ocean, was first reported in the southwest corner of the Gulf of Mexico in 2013, on coastal reefs near Coatzacoalcos (González-Gándara and Cruz-Francisco, 2014). Since then, the species was found on other reefs to the east and northwest of that location (de la Cruz-Francisco et al., 2015; Robertson et al., 2016), and more recently on oil platform

\footnotetext{
* Corresponding author at: Unidad Multidisciplinaria de Docencia e Investigación, Facultad de Ciencias, Universidad Nacional Autónoma de México, Sisal, Yucatán, Mexico.

E-mail addresses: nelly.tremblay@awi.de (N. Tremblay), edlin.guerra@ciencias.unam.mx (E.J. Guerra-Castro), fdiaz@cicese.mx (F. Díaz), grf@unam.mx (G. Rodríguez-Fuentes), ns@ciencias.unam.mx (N. Simões), drr@stri.org (D.R. Robertson), crv@ciencias.unam.mx (C. Rosas).

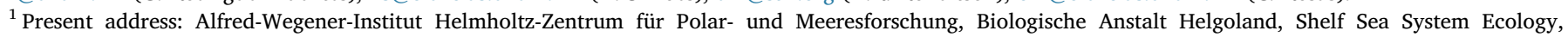
Helgoland, Germany.
} 


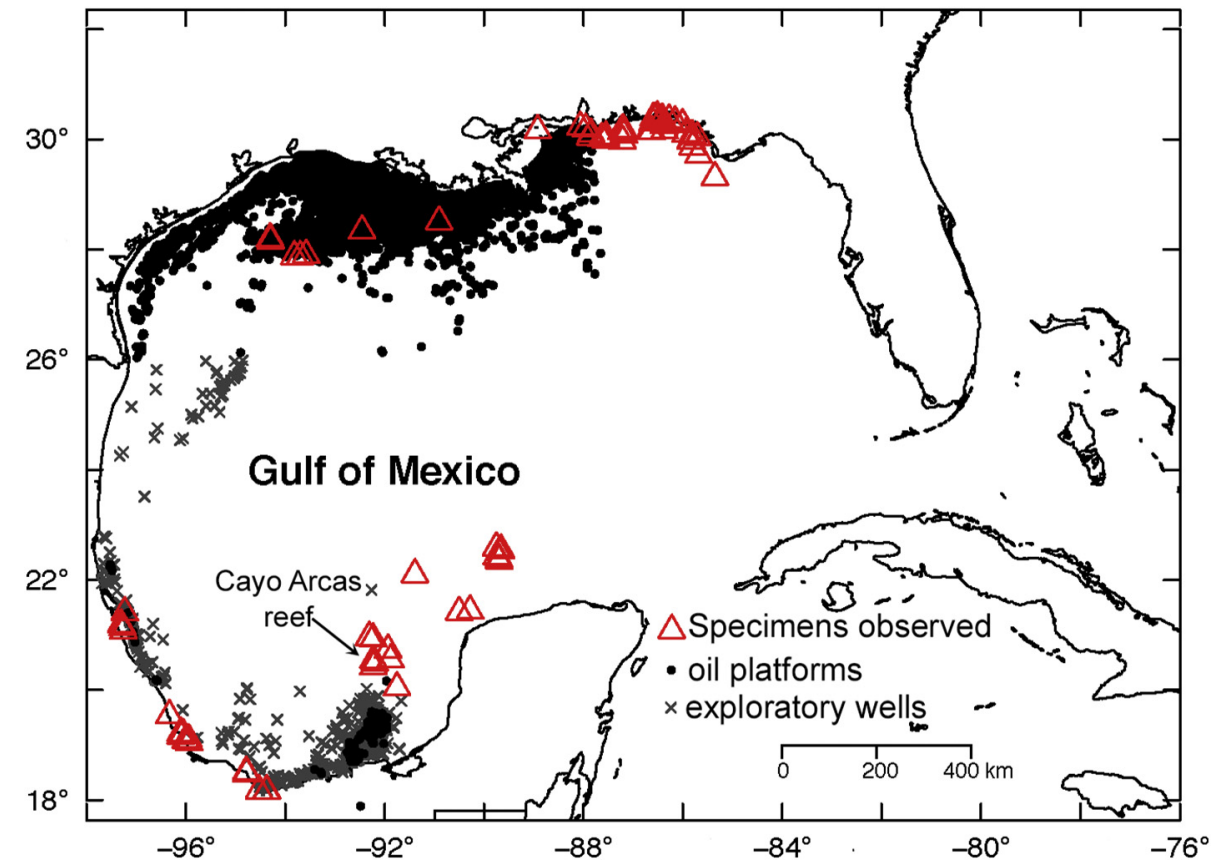

Fig. 1. Locations where $N$. cyanomos has been reported as of November 2019 (Nonindigenous Aquatic Species information resource for the United States Geological Survey; updated 25.11.2019; nas. er.usgs.gov/viewer/omap.aspx?SpeciesID = 2936; red triangles), with Cayo Arcas reef indicated and distribution of oil platforms in the entire Gulf of Mexico (filled black circles) and of exploratory wells in the Mexican section of that gulf (grey cross marks). (For interpretation of the references to colour in this figure legend, the reader is referred to the web version of this article.) structures, during the warmer months of 2016 and 2017, off the coast between Texas in the west and Alabama and the Florida panhandle in the east (Fig. 1) (Bennett et al., 2019; Schofield and Neilson, 2019). In the south, a massive aggregation has been observed under an oilloading platform adjacent to Cayo Arcas reef $350 \mathrm{~km}$ northeast of Coatzacoalcos (Simões and Robertson, 2016), between 0 and $45 \mathrm{~m}$ depths (DRR personal observations). Oil platforms host high fish biodiversity in many areas around the world (Claisse et al., 2014; Friedlander et al., 2014; Torquato et al., 2017), including the Gulf of Mexico (Hastings et al., 1976; Ajemian et al., 2015) and long-distance relocation of such platforms has been proposed as the vector of introduction of non-native fish species to the Canary Islands (Pajuelo et al., 2016) as well as the introduction of Neopomacentrus cyanomos to the southwest Gulf (Robertson et al., 2018). Given the ability of $N$. cyanomos to thrive on an oil platform, and its recent occurrence on platforms in the northern Gulf, it seems possible that this species has expanded its range permanently to that area. As, the lionfish (Pterois volitans) example has demonstrated, a spread of $N$. cyanomos to a much larger area is quite likely. In addition, this species was recently found in abundance at Trinidad (Robertson and Kingon, 2019) from where it could easily spread northwards throughout the Caribbean Sea.

Little information is available on the thermal tolerance to low temperatures of $N$. cyanomos that could indicate if this species can effectively colonize the Northern Gulf of Mexico, where low winter temperatures could limit its distribution. The present study examined physiological responses of $N$. cyanomos collected in the southwest Gulf of Mexico to low temperatures, with and without acclimation, to allow prediction of its capacity to survive through winter in the northern Gulf of Mexico. From an oceanographic point of view and working with pelagic larvae duration, Johnston and Akins (2016) highlighted the possibility that disconnection of surface currents between the southwest and northern zones of the Gulf likely would slow any spread northward of $N$. cyanomos. They did not include temperature or salinity in their model because the species was considered tolerant to a wide range of both parameters; e.g. it can breed in reduced-salinity conditions (Setu et al., 2010; Johnston and Akins, 2016).

Temperature has been shown to be the main drivers of the geographical distribution of marine species (Poloczanska, et al., 2016), and this is also true for alien species. The degree of thermal plasticity is crucial to defining where an organism can and cannot occur, while acclimation capacity reflects the potential of an organism to express a wider thermal tolerance range (Pörtner and Knust, 2007; Pörtner, 2010; Sokolova et al., 2012). To date, research on thermal tolerance of tropical reef fishes, including damselfishes, has mostly focused on effects of high temperatures, in order to assess potential effects of global warming. Johansen and Jones (2011) studied responses to several weeks of acclimation to temperatures $\sim 3{ }^{\circ} \mathrm{C}$ above prevailing summer conditions on the Australian Great Barrier Reef in $N$. cyanomos and nine other damselfishes in four genera. They observed a reduction of $\sim 2 / 3$ in the aerobic scope of these fishes, i.e. the energy available to maintain cellular processes and the potential capacity to convert energy in physical activity such as swimming. Also, significant mortality was observed in another damselfish (Acanthochromis polyacanthus) that was maintained at $3{ }^{\circ} \mathrm{C}$ above current average temperatures during ten months of acclimation (Rodgers et al., 2018).

A study of the effects of local winter sea surface temperatures $\left(23^{\circ} \mathrm{C}\right.$ SST) on the Great Barrier Reef on $N$. cyanomos, two other Neopomacentrus species and seven other damselfish species from three genera demonstrated that swimming performance was reduced under such conditions (Johansen et al., 2015). The species N. cyanomos, in its native range (see www.gbif.org/species/2398535; accessed November 25th, 2019), is exposed to average winter SSTs as low as $18{ }^{\circ} \mathrm{C}$ at sites such as southeast Africa, southeast Australia, the Gulf of Eilat, the Gulf of Oman, and southern Japan. This suggests that winter SSTs below $15{ }^{\circ} \mathrm{C}$ in the inshore areas of the northern zone of the Gulf of Mexico could slow down the permanent establishment of $N$. cyanomos. To test $N$. cyanomos' cold tolerance, we combined the results of two independent experiments involving several tested characters in individuals collected adjacent to a coral reef in the southwest Gulf of Mexico: 1) fish exposed to rapidly declining temperature; and 2) fish acclimated to reduced temperatures for sufficient time to allow the expression of compensatory mechanisms. Measurements of RMR, metabolites (in blood), and cellular stress markers (in muscle) were used to assess the cold tolerance of this alien species.

\section{Materials and methods}

\subsection{Animals}

The damselfish Neopomacentrus cyanomos were collected twice 
under an oil-loading platform $1.5 \mathrm{~km}$ from the Cayo Arcas reef $\left(20.21^{\circ} \mathrm{N},-91.98^{\circ} \mathrm{W}\right)$, in August $2016(n=16)$ and August 2017 $(n=30)$. Due to a lack of aquarium facilities at Cayo Arcas fish were collected only during the last two days of the diving campaign to preserve their physiological integrity until arrival to the experimental facilities. These logistic limitations explain the relatively small sample size. Divers captured specimens either by shaking fish out of tubular sponges they were using as hiding places into plastic bags that enveloped the sponges. Collecting methods were approved by the ACUC of the Smithsonian Tropical Research Institute (no. 2017-1107-2020). Fish were transported to the Unidad Multidisciplinaria de Docencia e Investigación de la Universidad Autónoma de México (UMDI-UNAM, Sisal, Mexico) and acclimatized in natural filtered $(5 \mu \mathrm{m})$ seawater for two weeks (in situ temperature, at $26 \pm 1{ }^{\circ} \mathrm{C}$ with salinity of 37), two to three individuals per aquarium $(11 L)$, with dissolved oxygen $>5.5 \mathrm{mg} \cdot \mathrm{L}^{-1}, \mathrm{pH}>8$, and a $12 \mathrm{~h}$ photoperiod. Fish were fed twice a day with Artemia nauplii in 2016 and with tropical fish flake food (Wardley, United-States of America) in 2017.

\subsubsection{Experiment 1: Acute decreasing temperature protocol}

All fish sampled in August 2016 ( $n=16$; wet weight or $\mathrm{WW}=2.67 \pm 0.99 \mathrm{~g}$ ) were transferred to a $25 \mathrm{~L}$ tank that was maintained at $26 \pm 1{ }^{\circ} \mathrm{C}$ and equipped with shelters and plastic grasses $72 \mathrm{~h}$ prior to the beginning of the decreasing temperature protocol. The acute-thermal-decline protocol was based on Norin et al. (2014) and consisted in exposing all fish simultaneously to decreasing temperature, by $-4{ }^{\circ} \mathrm{C}$ over a period of $1 \mathrm{~h}$, and maintaining that temperature for $23 \mathrm{~h}$. This protocol allowed the evaluation of the cumulative effect of a rapid decline (in three steps over three days) in temperature from $26^{\circ} \mathrm{C}$ to $14{ }^{\circ} \mathrm{C}$. Each tank was placed in a quiet and semi-dark environment to obtain the routine metabolic rate (RMR) and has enough space to accommodate both respirometry chambers (on stilts) and free-swimming fish. Four fish were randomly selected from the tank and placed individually in respiration chambers at $26{ }^{\circ} \mathrm{C}$ (see Section 2.2) to assess their baseline physiological state at in situ temperature. After $24 \mathrm{~h}$ in the respirometers, the four fish were sacrificed (decapitation) for blood metabolites and biochemical stress indicators (see Section 2.3). Then, another four fish were randomly selected from the tank, placed in the respirometry chambers and the seawater temperature of the whole system (respiration chambers and tank) was reduced to $22{ }^{\circ} \mathrm{C}$ over a period of $1 \mathrm{~h}$. Oxygen consumption of the fish within the respiration chambers was evaluated during the following $23 \mathrm{~h}$. That procedure was repeated every $24 \mathrm{~h}$ to expose fish sequentially to $22{ }^{\circ} \mathrm{C}, 18{ }^{\circ} \mathrm{C}$ and $14{ }^{\circ} \mathrm{C}$, with the individuals in the respirometers being sacrificed for biochemical analysis at the end of the $24 \mathrm{~h}$ exposure and replaced with other individuals. The replacement of the fish in the respiration chambers was intended to obtain independent respiration measurements of the cumulative effect of the rapid decline in temperature. Fish were fed twice a day with Artemia nauplii, except individuals inside the respiration chambers, which were not fed during the entire $24 \mathrm{~h}$ measurement. All $24 \mathrm{~h}$ measurements started at $10 \mathrm{am}$. As the exposure to $18{ }^{\circ} \mathrm{C}$ was lethal for one fish in the tank, only three fish were available for the $14{ }^{\circ} \mathrm{C}$ measurement.

\subsubsection{Experiment 2: Acclimation}

Fish collected from the Cayo Arcas platform in August 2017 $(n=30$; WW $=2.35 \pm 1.80 \mathrm{~g}$ ) were transferred individually to $3 \mathrm{~L}$ aquaria equipped with shelters at $26 \pm 1{ }^{\circ} \mathrm{C}$ in a controlled multiparameters system (Aquabiotech, Coaticook, Canada) at the laboratory of Applied Ecophysiology. The controlled multi-parameter system consists of four independent units with digital control of temperature and oxygen, each equipped with its own circulating and filtered seawater. Six $\left(26^{\circ}\right)$ to eight $\left(22^{\circ} \mathrm{C}, 20^{\circ} \mathrm{C}\right.$, and $\left.18{ }^{\circ} \mathrm{C}\right)$ aquariums were used per unit of the system. Fish were fed twice a day with tropical fish flake food (Wardley, United-States of America), except for $24 \mathrm{~h}$ prior to RMR measurement. To avoid mortality, the lowest temperature selected was
$18{ }^{\circ} \mathrm{C}$. The day after their transfer, the temperature of the three units containing each eight fish was decreased of $1{ }^{\circ} \mathrm{C}$ per day, at a rate of $0.1{ }^{\circ} \mathrm{C} \cdot \mathrm{h}^{-1}$ (the decrease of $1{ }^{\circ} \mathrm{C}$ started at $9 \mathrm{~h}$, ended at $19 \mathrm{~h}$ and the temperature was maintained until the next day) until 22,20 and $18{ }^{\circ} \mathrm{C}$ were reached, respectively. Once the target acclimation temperature was reached, a period of 45 days acclimation began. After this period, all fish were transferred individually to the respiration chambers at their acclimation temperature for $24 \mathrm{~h}$ (see Section 2.2). Respirometry chambers were maintained in a quiet and semi-dark environment to obtain the RMR of fish at each acclimation temperature. Subsequently, half of the fish were sacrificed (decapitation) for analyses of blood metabolites and biochemical stress indicators (see Section 2.3).

The remaining fish in the respiration chambers were used for a high temperature challenge. This challenge was designed to assess the effect of cold thermal acclimation on heat tolerance scope. It consisted in increasing by $1{ }^{\circ} \mathrm{C}$ the water circulating within the respiration chambers at a rate of $0.2^{\circ} \mathrm{C} \cdot \mathrm{min}^{-1}$. The temperature was maintained for $5 \mathrm{~min}$ at each degree of increase to assess if there was a noticeably increase of swimming activity, which we considered equivalent to escape behaviour. If no escape behaviour was observed, the temperature was increased $1{ }^{\circ} \mathrm{C}$ further following the same rate. When the first escape behaviour was noted the fish was sacrificed (decapitation) for blood metabolites and biochemical stress indicators analysis (see Section 2.3). The escape behaviour was observed at $25 \pm 3,28 \pm 2,28 \pm 3$ and $30 \pm 3{ }^{\circ} \mathrm{C}$ for the acclimation temperatures of $18,20,22$, and $26{ }^{\circ} \mathrm{C}$ respectively.

\subsection{Routine metabolic rates (RMR)}

RMR was measured using a continuous flow respirometer, with the respirometry chambers connected to a well-aerated open re-circulating seawater system at the experimental temperature (Rosas et al., 2008). To obtain a steady state of the system, the water was well-mixed and the measurement lasted 23 to $24 \mathrm{~h}$ to ensure that any change in fish oxygen consumption was revealed accurately in the out-flowing water, following Steffensen (1989) and Svendsen et al. (2016) recommendations. The volumes of the respiration chambers were of $100 \mathrm{~mL}$ or $500 \mathrm{~mL}$ to ensure fish movement without restrictions into the chamber. The water flow was measured at the beginning and at the end of the measurement by filling a graduated cylinder for a duration of $15 \mathrm{~s}$ and converting this volume in $\mathrm{L}^{-1}{ }^{-1}$. Measurements of dissolved oxygen $\left(\mathrm{mg} \cdot \mathrm{L}^{-1}\right)$ were recorded for each chamber (entrance and exit) every second using oxygen sensors attached to flow-cells that were connected by optical fibber to a witrox amplifier (Loligo Systems, Denmark). One empty chamber was used for each chamber size as a control to account for microbial oxygen consumption in the filtered seawater. The sensors were previously calibrated at each temperature using saturated seawater ( $100 \%$ air saturation) and a $5 \%$ sodium sulphate solution ( $0 \%$ air saturation) to obtain the phase values of each optical fibre coupled with its oxygen sensor. RMR was calculated as the difference in dissolved oxygen concentrations between the input and output of each chamber, with incorporation of the water-flow rate and the microbial oxygen consumption. The RMR values of fish exposed to acute decrease of temperature and of acclimated fish were selected using the $\mathrm{R}$ package 'fishMO2' created by Chabot (2016) following his recommendation (Chabot et al., 2016). Oxygen consumption data were expressed as $\mathrm{mg}$ $\mathrm{O}_{2} \cdot \mathrm{h}^{-1} \cdot \mathrm{g} \mathrm{WW}^{-1}$. The $\mathrm{Q}_{10}$ temperature coefficient was calculated with the respiration values of both experiments to give insights on the changing performance of the fish and their compensation capacity:

$Q_{10}=\left(\frac{\text { mean } R M R \text { at } T 2}{\text { mean } R M R \text { at } T 1}\right)^{\frac{10}{(T 2-T 1)}}$

where $\mathrm{T} 2$ and $\mathrm{T} 1$ corresponded to the highest and lowest acclimation temperature $\left({ }^{\circ} \mathrm{C}\right)$, respectively. The $\mathrm{Q}_{10}$ temperature coefficient can be calculated for intervals $<10{ }^{\circ} \mathrm{C}$ (Atkin and Tjoelker, 2003). Here we 
calculated $\mathrm{Q}_{10}$ for a minimum interval of $4{ }^{\circ} \mathrm{C}$.

\subsection{Metabolites and biochemical stress indicators analysis}

Metabolites and biochemical stress indicators were analysed in fish subject to three experimental treatments: 1) acute temperature reduction; 2) after RMR following acclimation to low temperature; 3) and after the high temperature challenge following acclimated fish RMR measurements. At the end of the respiration measurement, fish were collected one by one with an aquarium net, dried with tissue paper and weighted ( $\pm 0.01 \mathrm{~g}$; Ohaus Scout pro, USA). After wet weights were taken, fish were immediately decapitated. Fresh blood from the head was directly applied to lactate $\left[\mathrm{mM} \cdot \mathrm{L}^{-1}\right.$ ] (end-product of anaerobic metabolism) and glucose $\left[\mathrm{mg}^{\circ} \mathrm{dL}^{-1}\right]$ (principal energetic fuel) testing strips manufactured for use by the Accutrend Plus instrument (Roche Diagnostics, Mannheim, Germany), making sure that each strip was completely covered with blood (approximately $15 \mu \mathrm{L}$ ). Lactate and glucose values under the level of detection of the Accutrend apparel were assigned to half of the detection limit value for each metabolite (i.e. lactate: $0.35 \mathrm{mM} \cdot \mathrm{L}^{-1}$, glucose: $10 \mathrm{mg} \cdot \mathrm{dL}^{-1}$ ). This type of device has been widely used in applied studies to assess blood physiology parameters in teleost fish (Stoot et al., 2014).

Muscle tissue was separated on ice and snap frozen in liquid nitrogen, at the same time as the metabolite's measurement were made. Muscle samples were then transferred to an ultra-freezer at $-80{ }^{\circ} \mathrm{C}$ for later analysis in the Coastal Environmental Science Laboratory at Facultad de Química of UMDI-UNAM. Samples were homogenized in cold buffer Tris pH 7.4 at $100 \mathrm{mg}$ tissue $\cdot \mathrm{mL}^{-1}$ using a Potter-Elvejhem homogenizer. Subsequently, the muscle homogenate was divided for triplicate assays of several biochemical stress markers: activities of acetylcholinesterase (AChE; Ellman et al., 1961 adapted by RodríguezFuentes et al., 2008), carboxylesterase (CES; Hosokawa and Satoh, 2001 with modifications), catalase (CAT; Goth, 1991 modified by Hadwan and Abed, 2016), glutathione S-transferase (GST; Habig and Jakoby, 1981), superoxide dismutase (SOD; only in 2017; Sigma-Aldrich assay kit 19160), as well as quantification of carbonyls in oxidized proteins (CO; Mesquita et al., 2014), lipid peroxidation (LPO; SigmaAldrich PeroxiDetect Kit) levels, and total glutathione (GSH; only in 2017; Sigma-Aldrich Glutathione Assay Kit CS0260). All spectrophotometric measurements were made in a micro-plate reader and proteins were analysed in the supernatant following Bradford (1976) to standardize all enzyme activities in activity unit (U).mg protein ${ }^{-1}$. For AChE, CES, SOD, CAT, and GST activity assays, muscle homogenates were centrifuged at $10,000 \times g$ for $5 \mathrm{~min}$ at $4{ }^{\circ} \mathrm{C}$ and the supernatant was separated for analysis.

Citrate synthase (CS; Sidell et al., 1987), and lactate dehydrogenase (LDH; Lactate dehydrogenase-SL assay, Diagnostic Chemicals Limited) were only assessed in acclimated fish from the 2017 experiments, and were done to complement the energetic indicators analysis. CS is frequently measured as an indicator of mitochondrial density to assess the aerobic capacity in a tissue, while LDH catalyses the final step in anaerobic glycolysis through the conversion of pyruvate to lactate via coupled oxidation of reduced nicotinamide adenine dinucleotide to its oxidized form. These enzymes were analysed separately in a second aliquot of the fish muscle. Muscle samples were weighed in a Precellys homogenization tube (Sartorius LA230S, Goettingen, Germany) and diluted 1:20 $(w / v)$ with ice-cold TrizmaTM hydrochloride (Tris- $\mathrm{HCl}$ ) buffer [20 mM Tris-HCL, $1 \mathrm{mM}$ ethylenediaminetetraacetic acid (EDTA), $0.1 \%(v / v)$ Tween 20, pH 7.4]. Subsequently, tubes were placed in a homogenizer (Bertin Technologies - MINILYS, Montigny-leBretonneux, France) with the following cycle: $2 \cdot 10 \mathrm{~s}, 5000$ rotations. After centrifugation at $7400 \mathrm{xg}$ for $5 \mathrm{~min}$ at $4{ }^{\circ} \mathrm{C}$, the supernatant of the homogenate was removed and used for measurement.

\subsection{Statistical analysis}

A complete set of original data from all experiments is provided in the open access online data repository PANGAEA (doi:https://doi.org/ 10.1594/PANGAEA.891264). All statistical analyses were done using $\mathrm{R}$ ( $R$ core team, 2018). The package 'vegan' (Oksanen et al., 2019) was used to assess the effects of temperature in the physiological responses of fish for each set of experiments with distance-based multivariate statistics. First, physiological variables were normalized (centred on their means), and the homogeneity of the multivariate dispersion in the Euclidean space was tested with a multivariate analogue to Levene's test prior to permutational analysis of variance (PERMANOVA) procedure, using distances to centroids and 9999 permutations (Anderson, 2006). Subsequently, one-way PERMANOVA tests were performed based on Euclidean distances, the probability associated with the pseudo- $F$ statistic under a true null hypothesis being estimated with 9999 permutations (Anderson, 2017). If a significant difference was obtained, a pairwise multivariate $t$-test was done. For each experiment, the variables responsible for the differences between groups were then identified using decomposition of the Euclidean distance between each pair of samples and averaging the contributions of each variable to the differences between treatments (SIMPER analysis). Principal Component Analysis ordinations based on the correlation matrix revealed that, in neither case, the first two to three components accounted for $>50 \%$ of total variation. Consequently, non-metric multidimensional scaling (nMDS) plots were made for output visualization.

To support the PERMANOVA approach and visualize which variable influenced the stress responses, parameters were divided in two groups for an Integrated Biomarker Response (IBR) analysis (Beliaeff and Burgeot, 2002). IBR analysis have been employed in many eco-physiological studies to assess thermal acclimation of fishes and invertebrates (see Marigómez et al., 2013; Ferreira et al., 2015; Madeira et al., 2016, 2018, 2019). For this, energetic indicators (concentrations of lactate, glucose, WW, RMR, LDH and CS) and the biochemical stress indicators were analysed for each set of experiment (AChE, CES, SOD, GSH, CAT, GST, CO and LPO). The global response of both groups was summarized in one general "stress index" for each fish to assess the effect of low-temperature exposure or acclimation (following Li et al., 2016). Radar plots were done using the 'fmsb' package (Nakazawa, 2018) in $\mathrm{R}$ with mean scores.

The sample size (number of individuals per treatment), although small, was sufficient to allow establishment of large-magnitude effects using a power analysis of 0.8 and a significance level of Error Type I fixed at 95\% ( $\alpha=0.05$ ). Differences between RMR and IBR following the rapid-decrease temperature protocol and the 45-days acclimation were tested separately with one-way analysis of variance (ANOVA) and a Tukey post-hoc comparison. Data were checked for outliers with Cleveland dot plots, transformed (square root or logarithmic) and tested for normality (Shapiro-Wilk test) and variance homogeneity (Levene's test) prior to ANOVA. If criteria were not met, Kruskal-Wallis test was used and post-hoc comparison were realized with the package 'pgirmess' (Giraudoux, 2018).

\section{Results}

\subsection{Routine metabolic rates (RMR)}

\subsubsection{Acute temperature decrease protocol}

Neopomacentrus cyanomos exposed to the acute-decrease temperature protocol had higher RMR at $18{ }^{\circ} \mathrm{C}$ compared to $22{ }^{\circ} \mathrm{C}$ (ANOVA, $F_{(3,11)}=6.271, p=.010$; Table 1). Temperature coefficients of $\mathrm{Q}_{10}<1$ were observed when RMR of fish exposed to $14^{\circ} \mathrm{C}\left(\mathrm{Q}_{10}=0.5\right)$ and $18{ }^{\circ} \mathrm{C}\left(\mathrm{Q}_{10}=0.1\right)$ were compared with fish exposed to $22^{\circ} \mathrm{C}$, and when fish exposed to $18{ }^{\circ} \mathrm{C}\left(\mathrm{Q}_{10}=0.5\right)$ were compared with fish maintained at $26^{\circ} \mathrm{C}$. Values of $\mathrm{Q}_{10}>1$ were observed when RMR of fish exposed to $14{ }^{\circ} \mathrm{C}\left(\mathrm{Q}_{10}=1.1\right)$ and $22{ }^{\circ} \mathrm{C}\left(\mathrm{Q}_{10}=4.7\right)$ were compared 
Table 1

Routine metabolic rate (RMR; in $\mathrm{mg} \mathrm{O}_{2} \cdot \mathrm{h}^{-1} \cdot \mathrm{gWW}^{-1}$ ) of Neopomacentrus cyanomos exposed to an acute temperature decrease protocol (experiment 1) and acclimated 45 days (Experiment 2); (n) - number of individuals measured; Letters indicate significant differences; mean \pm standard error.

\begin{tabular}{lll}
\hline Temperature $\left({ }^{\circ} \mathrm{C}\right)$ & Experiment 1 & Experiment 2 \\
\hline 26 & $0.23 \pm 0.09(4)^{\mathrm{ab}}$ & $0.75 \pm 0.17(6)^{\mathrm{a}}$ \\
22 & $0.13 \pm 0.08(4)^{\mathrm{a}}$ & $0.86 \pm 0.35(8)^{\mathrm{a}}$ \\
20 & - & $0.44 \pm 0.27(8)^{\mathrm{b}}$ \\
18 & $0.43 \pm 0.13(4)^{\mathrm{b}}$ & $0.23 \pm 0.03(8)^{\mathrm{b}}$ \\
14 & $0.20 \pm 0.06(3)^{\mathrm{ab}}$ & - \\
\hline
\end{tabular}

with fish maintained at $26^{\circ} \mathrm{C}$. The highest $\mathrm{Q}_{10}$ value was obtained when fish exposed to $14{ }^{\circ} \mathrm{C}$ were compared with fish exposed to $18{ }^{\circ} \mathrm{C}$ $\left(\mathrm{Q}_{10}=6.5\right)$.

\subsubsection{Acclimation protocol}

When acclimated for 45 days, RMR of fish acclimated at warmer temperatures $\left(26^{\circ}\right.$ and $\left.22{ }^{\circ} \mathrm{C}\right)$ were higher than fish acclimated at cold temperatures $\left(20^{\circ}\right.$ and $18{ }^{\circ} \mathrm{C}$; ANOVA, $F_{(3,26)}=15.49, p<.000$; Table 1). Fish acclimated to $18{ }^{\circ} \mathrm{C}$ showed the highest $\mathrm{Q}_{10}$ values when their RMR was compared to that of fish acclimated to $22{ }^{\circ} \mathrm{C}$ $\left(Q_{10}=27.0\right)$. Intermediate values of $Q_{10}$ were obtained when $R M R$ at $18{ }^{\circ} \mathrm{C}$-exposure $\left(\mathrm{Q}_{10}=4.4\right)$ and $20{ }^{\circ} \mathrm{C}$-exposure $\left(\mathrm{Q}_{10}=2.4\right)$ were compared to those at $26^{\circ} \mathrm{C}$, while a low value $\left(\mathrm{Q}_{10}=0.7\right)$ was obtained when the RMR at $22{ }^{\circ} \mathrm{C}$ was compared with RMR at $26{ }^{\circ} \mathrm{C}$.

\subsection{Physiological proxies: Metabolites and biochemical parameters}

\subsubsection{Experiment 1: Acute temperature decrease protocol}

Rapidly decreasing temperature provoked significant changes in blood metabolites and antioxidant defence mechanisms in centroids of fish subject to declines down to 18 and $14{ }^{\circ} \mathrm{C}$ (PERMANOVA, pseudo$F_{(3,11)}=1.912, p=.009$; Fig. $2 \mathrm{~A}$ ), compared to $26{ }^{\circ} \mathrm{C}$ (paired-wise test). Energetical and biochemical stress IBR indices corroborated these changes with higher IBR values in the colder $v s$. warmer temperatures when integrating wet weight (WW), lactate (Lac), glucose (Glu), and RMR (ANOVA, $F_{(3,11)}=6.249, p=.010$; Fig. 3A). This difference probably was due to higher values of blood metabolites and RMR observed in fish exposed to 14 and $18{ }^{\circ} \mathrm{C}$ respectively (Fig. 3A). When integrating the biochemical stress variables, a lower IBR value at $14{ }^{\circ} \mathrm{C}$ compared to $26{ }^{\circ} \mathrm{C}$ (Kruskal-Wallis chi-squared (3,11) $=8.5167$, $p=.036$; Fig. 3B) was observed from lower activity of all enzymes, as well as lower protein carbonylation (CO), and a higher oxidative damage to lipids (LPO) in fish exposed to $14{ }^{\circ} \mathrm{C}$ (Fig. 3B).

\subsubsection{Experiment 2: Acclimation}

The effect of cold temperature acclimation on physiological proxies was evaluated using fish sampled immediately after the measurement of RMR. No significant changes in blood metabolites and antioxidant defence mechanisms were observed between centroids of fish acclimated to $18{ }^{\circ} \mathrm{C}$ and those maintained at $26{ }^{\circ} \mathrm{C}$ (PERMANOVA, pseudo$F_{(3,10)}=1.509, p=.077$; Fig. $\left.2 \mathrm{~B}\right)$. However, energetical IBR indices showed significant differences with higher IBR values in the warmer $v s$. colder temperature when integrating WW, Lac, Glu, RMR, lactate dehydrogenase (LDH) and citrate synthase (CS) activities (ANOVA, $\left.F_{(3,11)}=9.219, p=.002\right)$. These differences are probably due to lower values of RMR and CS activity observed in fish acclimated to 18 and $20{ }^{\circ} \mathrm{C}$, and to the lowest values of all parameters at $18{ }^{\circ} \mathrm{C}$ (Fig. 3C). When integrating the biochemical stress variables, no significant changes were observed (Fig. 3D). However, a bell-shaped thermal curve underpinned lowest levels of parameters at 18 and $26^{\circ} \mathrm{C}$ : At $26^{\circ} \mathrm{C}$, low acetylcholinesterase (AChE) and superoxide dismutase (SOD) activities were notable. At $18{ }^{\circ} \mathrm{C}$, fish maintained low levels of antioxidants, LPO and $\mathrm{CO}$ (Fig. 3D).

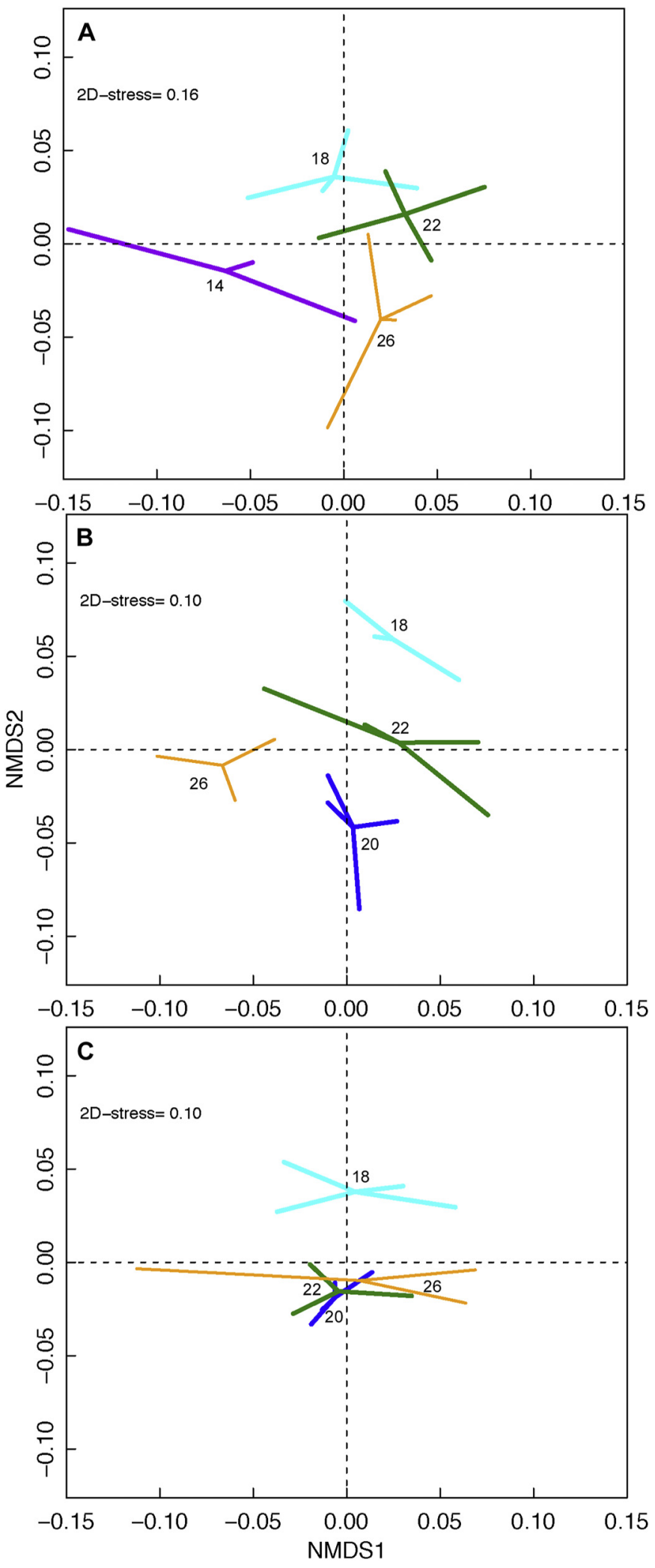

Fig. 2. Non-metric multidimensional scaling (nMDS) analyses showing Neopomacentrus cyanomos distance to centroids categorized by temperature $\left(14{ }^{\circ} \mathrm{C}=\right.$ purple; $18{ }^{\circ} \mathrm{C}=$ cyan; $20^{\circ} \mathrm{C}=$ blue; $22^{\circ} \mathrm{C}=$ green; $26{ }^{\circ} \mathrm{C}=$ orange $)$ in the physiological proxies (metabolites and biochemical parameters) space after (A) the acute decrease in temperature protocol (experiment 1), (B) the routine metabolic rate measurement post 45 days-acclimation (experiment 2, part 1), and (C) the high-temperature challenge post 45 days-acclimation (experiment 2, part 2). (For interpretation of the references to colour in this figure legend, the reader is referred to the web version of this article.) 

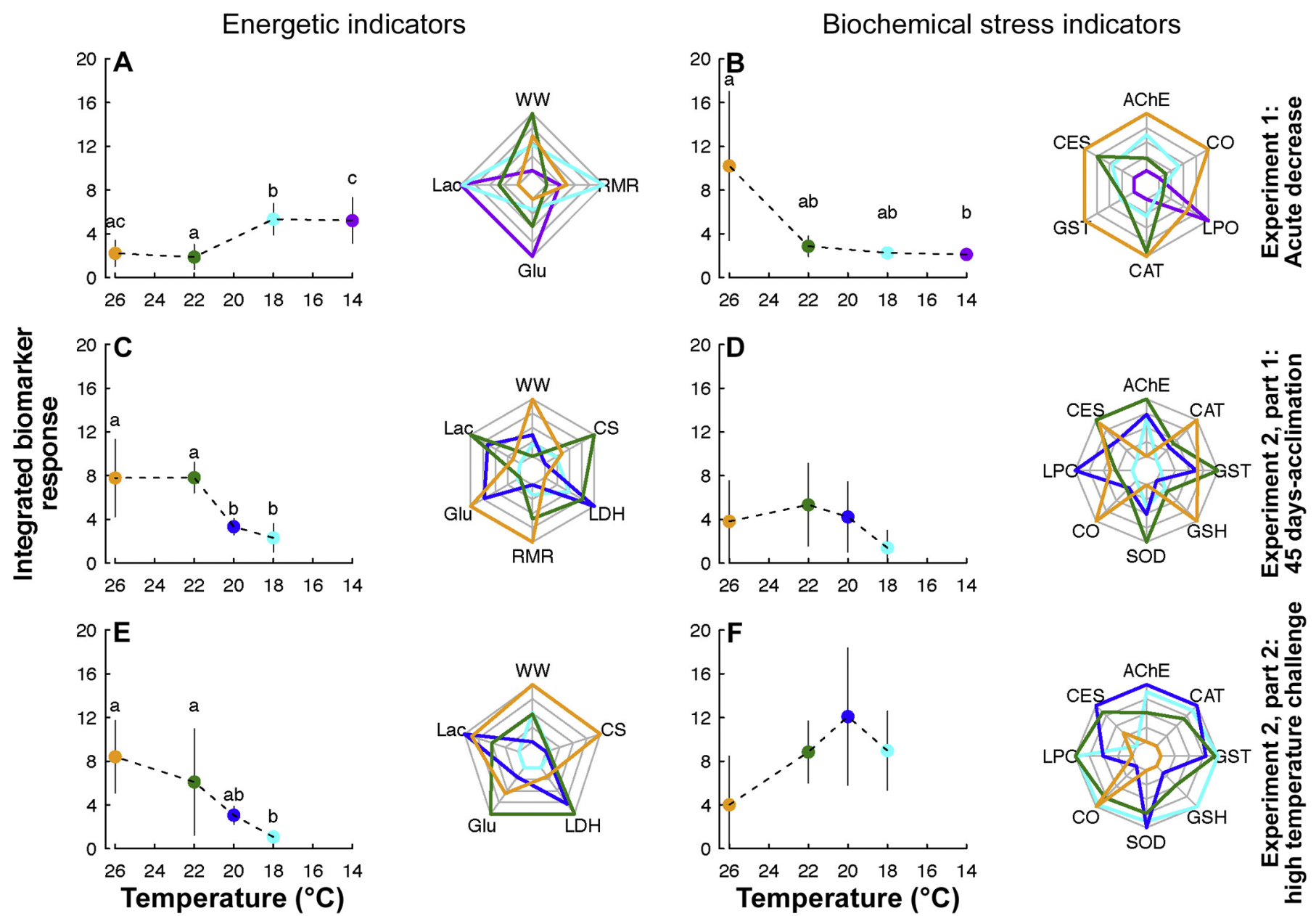

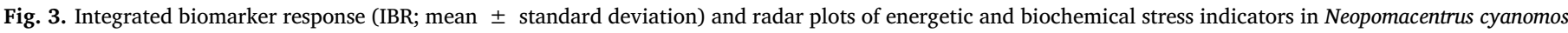

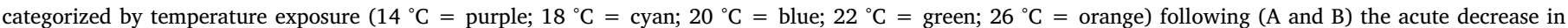

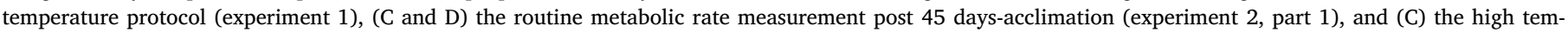

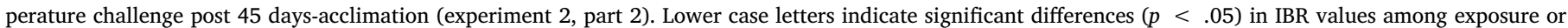

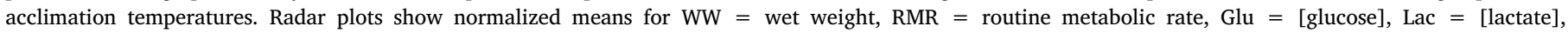

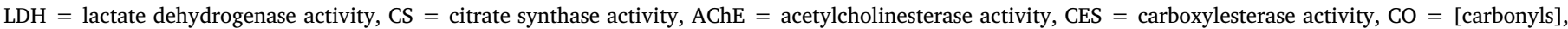

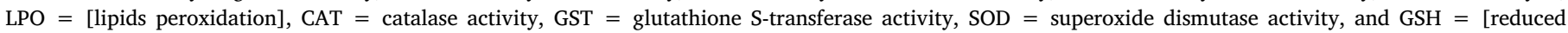
glutathione]. (For interpretation of the references to colour in this figure legend, the reader is referred to the web version of this article.)

When acclimated fish were thermally challenged, the acclimation temperature had a significant effect on the physiological proxies deployed at $20{ }^{\circ} \mathrm{C}$ compared to $18{ }^{\circ} \mathrm{C}$ (PERMANOVA, pseudo$F_{(3,10)}=1.831, p=.011$; pair-wise test; Fig. $2 \mathrm{C}$ ). Energetical IBR indices showed significant differences with higher IBR values in the warmer $\left(26\right.$ and $\left.22^{\circ} \mathrm{C}\right) v s .18{ }^{\circ} \mathrm{C}$ when integrating WW, Lac, Glu, LDH and CS (ANOVA, $F_{(3,11)}=6.635, p=.008$ ), probably due to comparably lower values of Lac and Glu observed in fish acclimated to $18{ }^{\circ} \mathrm{C}$ (Fig. 3E). Again, a non-significant bell curve trend was observed when integrating the biochemical stress variables, highlighting oxidative stress at $18{ }^{\circ} \mathrm{C}$ as all antioxidant levels and indicators of damages were increased (Fig. 3F). Oxidative damages were not observed in fish acclimated to $20^{\circ} \mathrm{C}$.

\section{Discussion}

Limited sample sizes likely constraint the inferences that can be drawn from the results presented here. However, any direct information about alien specimens in the newly colonized area reduces the need to use of information from secondary sources to predict invasion success, which will increase accuracy of models about such success (Lyons et al., 2019). Lennox et al. (2015) have highlighted the fact that very few studies have made physiological assessments of invasive species. The present study was designed to obtain as much physiological information as possible we could get from a small sample of alien Neopomacentrus cyanomos individuals to offset the data deficiencies often reported outside of species native ranges.

The three approaches used here (respirometry, energy metabolites in blood, and biochemical indicators in muscle) in two different experiments involving rapidly and slowly decreasing temperatures show that fish maintained at warm temperatures $\left(22\right.$ and $\left.26^{\circ} \mathrm{C}\right)$ differed from those that were rapidly reduced to $14{ }^{\circ} \mathrm{C}$ or were acclimated to 18 and $20{ }^{\circ} \mathrm{C}$ for 45 -days. Overall, our results show that when the degree of temperature change was large and rapid, no compensation occurred and the stress response observed mostly reflected cellular processes that minimized damage (Clarke, 1991). However, while a set of physiological proxies responded to minimize damage during the rapid-decrease experiment, the same proxies reflected the consequences of compensation in the second, 45-days of acclimation, experiment.

\subsection{No compensation when temperature decreases rapidly}

Results obtained in the first experiment (acute temperature decline) showed that fish were unable to regulate their metabolic rate to cope 
with a change towards low temperatures, as shown by the increased routine metabolic rate (RMR) when they reached $18{ }^{\circ} \mathrm{C}$. In this experiment, effective compensation, i.e. a reduction on respiratory rates, was only observed in fish exposed to the first temperature decrease step $\left(26^{\circ}\right.$ to $22{ }^{\circ} \mathrm{C}$ ), which was strongly dependent on temperature $\left(\mathrm{Q}_{10}=4.7\right)$. From $22{ }^{\circ} \mathrm{C}$ to $18{ }^{\circ} \mathrm{C}$ or $14{ }^{\circ} \mathrm{C}, \mathrm{Q}_{10}$ values $<1$ indicate overcompensation, i.e. extra energy was consumed (see Precht, 1958). In other words, metabolism did not decrease with decreasing temperature, perhaps related to higher swimming activity behaviour aimed at avoiding low temperatures (Habary et al., 2017). Accumulated thermal stress following declines of $12{ }^{\circ} \mathrm{C}$ (from $26{ }^{\circ} \mathrm{C}$ to $14{ }^{\circ} \mathrm{C}$ ) provoked increases in blood lactate (Lac) and glucose (Glu) levels, indicating that fish used all their physiological resources to maintain a high metabolic rate that might eventually have allowed them to escape to warmer habitat if such was possible. Blood Glu changes observed in $N$. cyanomos followed similar trends as those seen in the red spotted grouper Epinephelus akaara (habitat temperature range $11.7^{\circ}-26.3^{\circ} \mathrm{C}$ ) exposed to a temperature decrease from $10{ }^{\circ} \mathrm{C}$ to $4{ }^{\circ} \mathrm{C}$ at a rate of $1{ }^{\circ} \mathrm{C} \cdot \mathrm{d}^{-1}$ (Park et al., 2016), and in the genetically modified farmed tilapia, Oreochromis niloticus (optimal temperature range of $26^{\circ}-29^{\circ} \mathrm{C}$ ) after 24 h exposure to $13{ }^{\circ} \mathrm{C}$ (He et al., 2015). Umminger (1970) studied in detail the role of serum Glu in providing energetic fuel in the killifish Fundulus heteroclitus (habitat temperature range $6^{\circ}-35{ }^{\circ} \mathrm{C}$ ) exposed to extremely low temperature $\left(-1.5{ }^{\circ} \mathrm{C}\right)$. He found that the increased serum Glu was accompanied by a progressive depletion of hepatic glycogen, and that fish survived only as long as Glu was available. Thus, at the lowest temperature of the present study $\left(14{ }^{\circ} \mathrm{C}\right)$, regal damselfish probably had little energy left to maintain activity and repair cell damage caused by the accumulated stress of a rapid decrease in temperature. At this temperature, cell damage was evident from the accumulation of lipid peroxidation (LPO), there was a general decrease in antioxidant enzyme defence activities, and an inhibition of acetylcholinesterase (AChE) activity, indicating a lower efficiency in breaking down acetylcholine molecules essential for the communication between nervous and muscle cells. The high $\mathrm{Q}_{10}$ value of $6.5 \mathrm{ob}-$ tained for a comparison of fish exposed to $14{ }^{\circ} \mathrm{C} v s .18{ }^{\circ} \mathrm{C}$ indicates that fish were completely exhausted by the acute exposure to $14{ }^{\circ} \mathrm{C}$.

Values of carbonyls in proteins (CO) were surprisingly high in $N$. cyanomos maintained at $26{ }^{\circ} \mathrm{C}$ compared to fish at all reduced temperatures. The opposite would be expected, as fish exposed to $14{ }^{\circ} \mathrm{C}$ demonstrated more signs of stress than did fish maintained at $26{ }^{\circ} \mathrm{C}$. Since the temperature throughout the Gulf is at or above $26^{\circ} \mathrm{C}$ during August, when the fish were collected, physiological responses at this temperature prior to the rapid-decrease temperature experiment correspond approximately to the state at which the habitat was successfully colonized by this species. While high CO levels at $26{ }^{\circ} \mathrm{C}$ may indicate some oxidative stress, they may also represent a mechanism of protein-quality control in the unstressed fish, by making proteins more easily targeted by proteolytic degradation (Dukan et al., 2000; Bota and Davies, 2002). Rapid exposure to reduced temperatures could have stimulated proteasome mechanisms, which could explain the lower concentrations of $\mathrm{CO}$ observed at $22{ }^{\circ} \mathrm{C}, 18{ }^{\circ} \mathrm{C}$, and $14{ }^{\circ} \mathrm{C}$. Protein degradation found in a mutant yeast deficient in proteasome substrates that was exposed to cold temperature suggest the activation of apoptosis (Isasa et al., 2016). In a tropical fish species (Nothobranchius rachovii), an extended lifespan was correlated with lower $\mathrm{CO}$ values during moderate $\left(25^{\circ} \mathrm{C}\right)$ and low $\left(20^{\circ} \mathrm{C}\right)$ acclimation temperatures (Hsu and Chiu, 2009) was also observed. The authors of that study suggested that cold temperatures enhanced proteolytic degradation efficiency, provoking a reduction in aging. Lamarre et al. (2010) also noted high $20 \mathrm{~S}$ proteasome activity in juvenile spotted wolffish (Anarhichas minor Olafsen) acclimated to cold temperatures $\left(4{ }^{\circ} \mathrm{C}\right)$, reaching levels $130 \%$ of that of fish acclimated to $8{ }^{\circ} \mathrm{C}$ when measured at a common temperature. Perhaps, a similar beneficial mechanism activated in response to cold temperatures is also present in $N$. cyanomos subject to rapid decreases of temperature.

\subsection{Cost of compensation when temperature decreases slowly and cold} persists

Acclimation, which represents short-term adaptation to a new environmental circumstance, is mostly physiologically or metabolically based. Results obtained in the second experiment described here (acclimation to reduced temperatures for 45 days) showed that fish were able to regulate their metabolic rate relative to colder thermal conditions. This was shown by the decrease of RMR at 20 and $18{ }^{\circ} \mathrm{C}$, suggesting energy saving. The reduction of RMR at $18{ }^{\circ} \mathrm{C}$ and $20{ }^{\circ} \mathrm{C}$ coincides with the reduction of citrate synthase (CS) activity, which is the pacemaker of aerobic mitochondrial respiration. The decrease of RMR and CS activity would mean that mitochondrial biogenesis was not induced in response to cold temperature, as has often been observed in polar fishes (O'Brien, 2011). This translates into a lower concentration of aerobic metabolic enzymes per gram of tissue to maintain ATP production, a lower density of mitochondrial membrane phospholipids to enhance oxygen diffusion, and greater diffusion distance for oxygen and metabolites between capillaries and mitochondria. The strong effects of temperature on RMR of $N$. cyanomos were evidenced by the high $\mathrm{Q}_{10}$ values obtained when the RMR of damselfish acclimated at $18{ }^{\circ} \mathrm{C}$ were compared with those acclimated at $22{ }^{\circ} \mathrm{C}\left(\mathrm{Q}_{10}=27.0\right)$ and $26{ }^{\circ} \mathrm{C}$ $\left(Q_{10}=4.4\right)$. In other words, fish at $18{ }^{\circ} \mathrm{C}$ were outside their normal temperature range, and were obliged to invest greater energy to maintain their RMR. The slight decrease of performance $\left(\mathrm{Q}_{10}=0.7\right)$ noted between fish acclimated at $22{ }^{\circ} \mathrm{C}$ and those maintained at $26{ }^{\circ} \mathrm{C}$, and the typical $Q_{10}$ value (between 2 and 3) obtained when comparing fish at $20^{\circ} \mathrm{C}$ and $26^{\circ} \mathrm{C}$, provide evidence that between $20{ }^{\circ} \mathrm{C}$ and $26^{\circ} \mathrm{C}$ (and probably higher temperatures) $\mathrm{N}$. cyanomos has the physiological mechanisms to compensate for thermal decrements (Precht, 1958). In other damselfish species, typical $\mathrm{Q}_{10}$ values were observed when fish were exposed to $29-31{ }^{\circ} \mathrm{C}$, suggesting that this thermal range is where physiological mechanisms are optimal for typical conditions in their native habitat (Nilsson et al., 2009; Rummer et al., 2014).

As $26{ }^{\circ} \mathrm{C}$ represents the summer habitat temperature for the experimental $N$. cyanomos, it is unlikely that low AChE activity at that temperature indicates failure between the nervous and locomotor systems. That reduction of AChE activity could be explained by the differential effects of temperature on the Michaelis constant $\left(\mathrm{K}_{\mathrm{m}}\right)$ of acetylcholine between AChE isoforms. Baldwin and Hochachka (1970), in a study on the rainbow-trout Oncorhynchus mykiss (habitat temperature range of $10^{\circ}-24{ }^{\circ} \mathrm{C}$ ), detected a warm and a cold variant of AChE in the brain after acclimatization to warm $\left(17^{\circ} \mathrm{C}\right)$ and cold $\left(2{ }^{\circ} \mathrm{C}\right)$ conditions, respectively, and the presence of both variants at an intermediate temperature $\left(12{ }^{\circ} \mathrm{C}\right)$. Because the AChE assay used here measures the total activity of the enzyme without discriminating among any variants that may have been activated, we suggest that AChE generally operates more efficiently in $N$. cyanomos acclimated to colder temperatures $\left(18{ }^{\circ} \mathrm{C}, 20{ }^{\circ} \mathrm{C}\right.$ and $\left.22{ }^{\circ} \mathrm{C}\right)$ compared to those acclimated to $26^{\circ} \mathrm{C}$. A similar decrease in AChE activity was observed in the digestive gland of the mussel Modiolus barbatus after 20 and 30 days of warm acclimation at $28{ }^{\circ} \mathrm{C}$ and $30{ }^{\circ} \mathrm{C}$, compared to a shorter acclimation of 10 days (Dimitriadis et al., 2012).

$N$. cyanomos acclimated to $18{ }^{\circ} \mathrm{C}$ was observed to feed less than fish acclimated to all other temperatures (NT, personal observations), behaviour that may account for the reduced swimming performance of foraging planktivorous fishes during winter in the field study of Johansen et al. (2015). Below $20{ }^{\circ} \mathrm{C}$, energetic reserves of $N$. cyanomos were depleted, as indicated by reduced concentrations of metabolic fuels (Glu), as well as reduced activity of carboxylesterase (CES) and lactate dehydrogenase (LDH). The lack of acquisition of energy by means of feeding and the high maintenance costs at low temperatures may have affected lipid and carbohydrate reserves of $N$. cyanomos, resulting in lower activity levels of both enzymes as both require lipids and carbohydrates to function. Whereas CES is involved in cell detoxification and lipid metabolism (Ross et al., 2010), LDH converts 

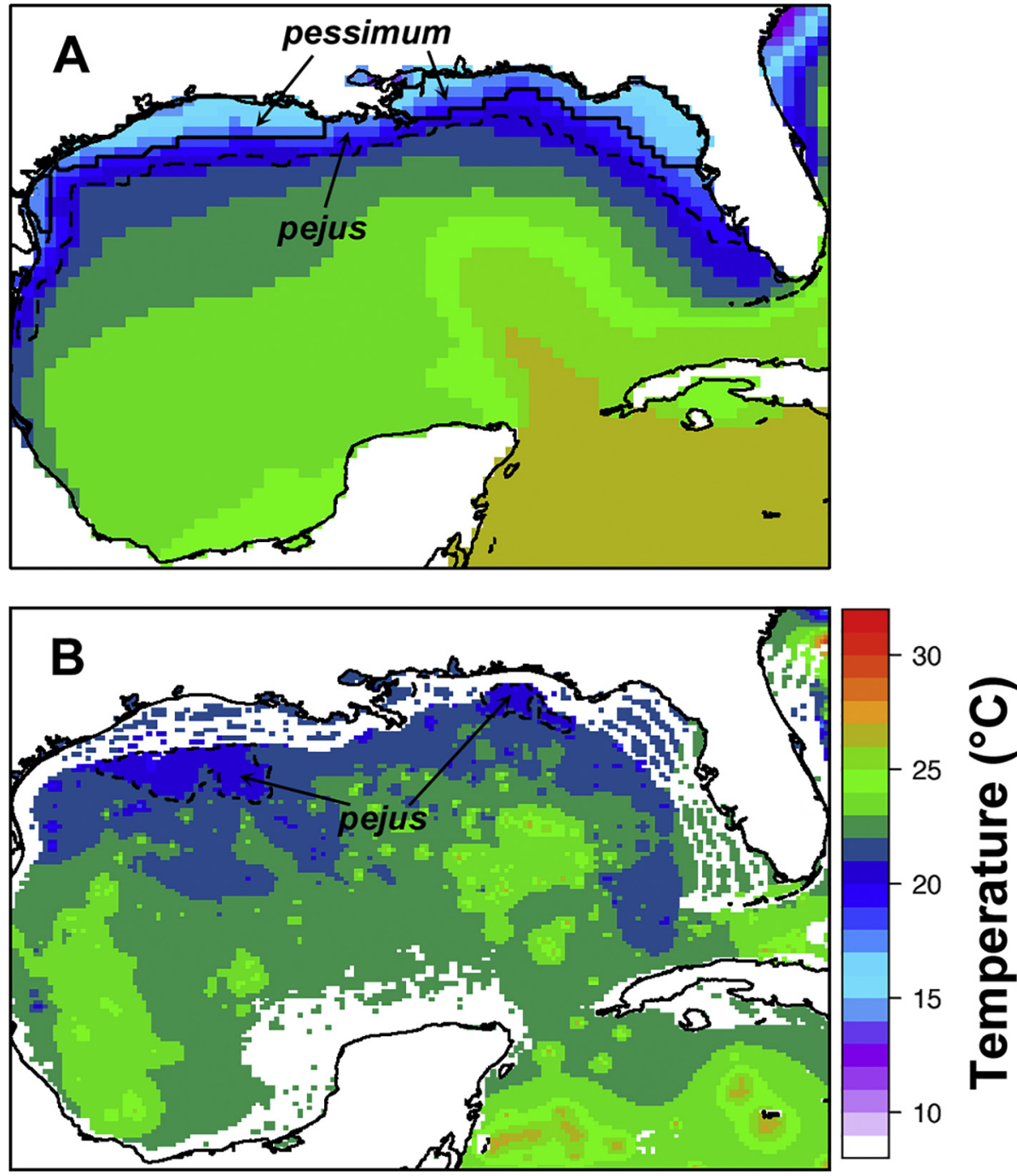

Fig. 4. Pejus and pessimum range thermal zones for Neopomacentrus cyanomos. Coldest mean sea surface temperature (A), and at 40-50 m (B) during 2000-2018, with pejus $\left(20-18{ }^{\circ} \mathrm{C}\right)$ and pessimum $\left(<18{ }^{\circ} \mathrm{C}\right.$ ) range thermal stress zones for $N$. cyanomos. Pejus corresponds to a physiological state in which the maintenance cost increases and is partly covered by the use of anaerobic metabolism, with fluctuations in mechanisms that compensate for the excess of reactive oxygen species produced by aerobic metabolism. Pessimum range will be lethal under prolonged exposure as all energy will be likely directed to maintenance and repair. Sea surface temperatures for the Gulf of Mexico during 2000-2018 were downloaded from NOAA High-resolution Blended Analysis provided by the NOAA/ OAR/ESRL PSD (Boulder, Colorado, USA, http:// www.esrl.noaa.gov/psd/). $\mathrm{R}$ packages 'ncdf4' (Pierce, 2015) and 'chron' (James and Hornik, 2016) were used to extract the data, and daily data were averaged per month using 'matrixStats' (Bengtsson, 2016). The 'Lattice' (Sarkar, 2008) package was used to display the visualizations. Temperatures at 40-50 m were extracted and monthly averaged from the World Ocean Database (Boyer et al., 2013; www. nodc.noaa.gov/OC5/SELECT/dbsearch/dbsearch.

html). The $40 \mathrm{~m}$ isobath (gcoos.tamu.edu/products/ topography/SRTM30PLUS.html) and the package "tmap" (Tennekes, 2017) was used for the interpolation. pyruvate into lactate to produce energy in absence of oxygen. In $N$. cyanomos acclimated to $18{ }^{\circ} \mathrm{C}$, some enzymatic and non-enzymatic antioxidants remained although such fish had lower levels of LPO and $\mathrm{CO}$ compared to fish maintained at $26^{\circ} \mathrm{C}$. Similarly to what occurred in the acute decreasing temperature protocol (experiment 1), cold temperature acclimation could have stimulated proteasome mechanisms, explaining the existence of lower concentrations of $\mathrm{CO}$ at $18{ }^{\circ} \mathrm{C}$.

\subsection{Thermal acclimation effects via high temperature challenge}

To reach their new habitat, the exotic specimens often undergo strong gradients in physic-chemical conditions that require a phenotypic plasticity often not experienced in their native distribution range. The high temperature challenge described here was useful in assessing what physiological plasticity remained after a potentially costly acclimation to a temperature outside of the comfort zone. Reduced feeding and maintenance costs at low temperatures may have affected the lipid and carbohydrate reserves, which resulted in decrease of CS, CES and LDH activities, as was the case in acclimated $N$. cyanomos after RMR measurements. The high levels of all antioxidant enzymes and compound (reduced glutathione) and oxidative damages (LPO and CO) in the cold-acclimated $N$. cyanomos submitted to high temperature challenges indicate an imbalance in reactive oxygen species (ROS) production caused by over- and under-oxygenation of tissues. The high temperature challenge activated energetic indices, but did not increase any biochemical stress markers in fish acclimated at $26{ }^{\circ} \mathrm{C}$, indicating that these fish had the cellular capability to deal with this sudden temperature increase. Fish acclimated to colder temperatures increased their integrated biomarker response (IBR) when subject to increased temperature challenge, indicating reduced plasticity to respond to increased temperature.

\subsection{Optimum, pejus, pessimum, and future conditions in the Gulf of Mexico}

The oxygen- and capacity-limited thermal tolerance hypothesis (Pörtner and Knust, 2007; Pörtner, 2010) proposes that optimal capacity exists when aquatic ectotherms show maximal aerobic scope, a physiological state characterized by low lactate and antioxidant levels, and reflecting low levels of peroxidation. Beyond the optimum limits, maintenance cost increases, reducing the amount of ATP available to cover completely those physiological demands. The ranges of temperatures that provoke such conditions are called pejus ranges and reflect acclimation, a physiological state marked by increased anaerobic metabolism to satisfy the energy demands that the aerobic metabolism cannot support. Beyond the pejus range ectotherms enter the pessimum range, where all the ATP is theoretically directed to maintenance and repair mechanism (Pörtner, 2010; Sokolova et al., 2012). The combined results of both experiments indicate that the three states of acclimation to low temperatures described by the oxygen- and capacity-limited thermal tolerance hypothesis were observed in N. cyanomos: 1 ) it has an optimum range $\left(26^{\circ}-22{ }^{\circ} \mathrm{C}\right)$, when fish are able to compensate and use energy supply to cover maintenance costs and maintain maximal 
physiological functions; 2) it has a pejus range (between $20{ }^{\circ} \mathrm{C}$ and $18^{\circ} \mathrm{C}$ ), in which the maintenance cost increases and is partly covered by anaerobic metabolism, with fluctuations in defence mechanisms to compensate for the excess of reactive oxygen species produced by aerobic metabolism; and 3) it has a pessimum range, the least favourable conditions under which an organism can survive (here between $18{ }^{\circ} \mathrm{C}$ and $14{ }^{\circ} \mathrm{C}$ ), when all energy is theoretically directed to maintenance and repair mechanisms and when time of exposure to low temperatures becomes crucial. The agreement between the critical temperature range indicated by our experiments and the minimum temperatures at the limits of the native range provides evidence that $N$. cyanomos is unlikely to survive well in habitats that experience minimum temperatures below $20^{\circ} \mathrm{C}$, the acclimation temperature at which its respiration rate is significantly reduced.

The question arising from our experimental results and the minimum temperatures at the latitudinal limits of $N$. cyanomos' native range is whether physiological limitations due to low winter temperatures could prevent this species establishing a persistent resident population in the northern Gulf of Mexico? Exploratory oil platforms off northwest Mexico between 24 and $26^{\circ} \mathrm{N}$ (Fig. 1) could allow N. cyanomos to fill the gap in its distribution between the Mexican platform grid and the several thousand oil platforms located in northern, US section of the Gulf. Based on the physiological constraints to low temperatures and the mean SST during the coldest month (February) between 2000 and 2018 (Fig. 4A), we conclude that $N$. cyanomos will not survive near the surface during the coldest months at locations experiencing pessimum state temperatures. However, winter temperatures at $40-50 \mathrm{~m}$ depth in the northern Gulf are consistently above the pessimum upper limit $\left(18{ }^{\circ} \mathrm{C}\right)$, and pejus conditions $\left(18^{\circ}-20^{\circ} \mathrm{C}\right)$ are not present over the entire northern Gulf at that depth, particularly on the outer parts of the continental shelf and slope (Fig. 4B). The ability of $N$. cyanomos to live at depths between 40 and $50 \mathrm{~m}$ may well mean that parts of a population in the northern Gulf can avoid adverse temperature conditions in the surface layers. Fish may use this strategy during winter off Alabama, as the presence of many early-stage juvenile specimens along with large adults there in July 2017 suggests that the species likely survived the winter conditions of 2016 (Bennett et al., 2019). Use of deeper warmer waters during the night has been observed during periods of low SST in the Atlantic cod Gadus morhua (Freitas et al., 2015), and N. cyanomos potentially could respond by moving to deeper areas (if available in the immediate vicinity) during cold periods.

Hence for the time being, $N$. cyanomos is likely to be limited to yearround persistence at subsurface levels of platforms located on the outer shelf and deep water far from the coast. However, on-going global warming is resulting in tropicalization of many temperate regions, including the northern Gulf, where it is facilitating expansion of native tropical western Atlantic shore-fish species into near-shore habitats (e.g. Gericke et al., 2014). Continuation of this tropicalization process should facilitate the expansion and establishment of $N$. cyanomos on platforms in inshore areas as well as deeper offshore areas. Oil-platform habitat is already populated by a variety of tropical West Atlantic native fishes, including planktivorous damselfishes of genera other than Neopomacentrus (Stegastes, Chromis and Abudefduf; see Hastings et al., 1976, Ajemian et al., 2015), with which N. cyanomos could compete for food, shelter and nest sites.

\section{Concluding remarks}

Based on the results of the present work, it is now clear that winter sea surface temperatures in the northern Gulf will slow down $N$. cyanomos to colonize the inshore area. The use of physiological cellular stress markers to assess the invasiveness potential of aquatic species, particularly at the start of an invasion, should be implemented in new standardized experimental protocols, including rapid increases/decreases of temperature and post-acclimation high temperature challenge. The output of experiments such as these could be integrated in replicable risk analysis that would provide clear tools to decision makers prior to the widespread establishment of invasive species in newly colonized habitat.

\section{Funding}

This study was partially financed by the Universidad Nacional Autónoma de México (UNAM) through its Programa de Apoyo a Proyectos de Investigación e Innovación Tecnológica [CR IN 204019] and Consejo Nacional de Ciencia y Tecnología (CONACYT) infrastructure 294028 grant to CR. Thanks are given to CONACYT scholarship no. 264554 awarded to FD for a national sabbatical stay and to the Dirección General de Asuntos del Personal Académico-UNAM for a Postdoctoral position to NT. The collection of the specimen was possible by the project "Biodiversidad Marina del Sur del Golfo de México" directed by NS and funded by Harte Research Institute of Texas A\&M University and the Comisión nacional para el conocimiento y uso de la biodiversidad (CONABIO - NE 018).

\section{Declaration of Competing Interest}

The authors declare that they have no known competing financial interests or personal relationships that could have appeared to influence the work reported in this paper.

\section{Acknowledgements}

We thank Yoalli Quetzalli Hernández Díaz, Antar Mijail Pérez Botello, Francisco de Atocha Puc Itza, Arturo Isaí Domínguez Guerrero, Jazmín Deneb Ortigosa Gutiérrez, and Sofía Isabel Valdés Ramírez for help with collecting specimens; the technical assistance provided by Claudia Caamal-Monsreal and Karen Ortega for the biochemical stress indicators analysis; the assistance of the students of the applied ecophysiology courses at UNAM-SISAL in the first experiment of 2016; and the assistance of Sadot Ramos Rodríguez and Kevin Ceballos Huicab for the 2017 experiments. Special thanks to the editor and one anonymous reviewer for the improvement of this manuscript.

\section{References}

Ajemian, M.J., Wetz, J.J., Shipley-Lozano, B., Shively, J.D., Stunz, G.W., 2015. An analysis of artificial reef fish community structure along the northwestern Gulf of Mexico shelf: potential impacts of "rigs-to-reefs" programs. PLoS One 10https://doi.org/10. 1371/journal.pone.0126354. e0126354-22.

Anderson, M.J., 2006. Distance-based tests for homogeneity of multivariate dispersions. Biometrics. 62, 245-253. https://doi.org/10.1111/j.1541-0420.2005.00440.x.

Anderson, M.J., 2017. Permutational multivariate analysis of variance (PERMANOVA). In: In: Wiley StatsRef: Statistics Reference Online. John Wiley \& Sons, Ltd..

Atkin, O.K., Tjoelker, M.G., 2003. Thermal acclimation and the dynamic response of plant respiration to temperature. Trends Plant Sci. 8, 343-351. https://doi.org/10.1016/ S1360-1385(03)00136-5.

Baldwin, J., Hochachka, P.W., 1970. Functional significance of isoenzymes in thermal acclimatization; acetylcholinesterase from trout brain. Biochem. J. 116, 883-887. https://doi.org/10.1042/bj1160883.

Beliaeff, B., Burgeot, T., 2002. Integrated biomarker response: a useful tool for ecological risk assessment. Environ. Toxicol. Chem. 21, 1316-1322. https://doi.org/10.1002/ etc. 5620210629 .

Bengtsson, H., 2016. matrixStats: Functions that Apply to Rows and Columns of Matrices (and to Vectors). In: R package version 0.50.2.

Bennett, C.T., Robertson, A., Patterson III, W.F., 2019. First record of the non-indigenous indo-Pacific damselfish, Neopomacentrus cyanomos (Bleeker, 1856) in the northern Gulf of Mexico. BioInvasions Records. 8, 154-166. https://doi.org/10.3391/bir. 2019.8.1.17.

Bota, D.A., Davies, K.J.A., 2002. Lon protease preferentially degrades oxidized mitochondrial aconitase by an ATP-stimulated mechanism. Nat. Cell Biol. 4, 674-680. https://doi.org/10.1038/ncb836.

Boyer, T.P., Antonov, J.I., Baranova, O.K., Coleman, C., Garcia, H.E., Grodsky, A., Johnson, D.R., Locarnini, R.A., Mishonov, A.V., O'Brien, T.D., Paver, C.R., Reagan, J.R., Seidov, D., Smolyar, I.V., Zweng, M.M., 2013. World Ocean Database. In: Levitus, S. (Ed.), Mishonov A (technical ed) NOAA Atlas NESDIS 72. Silver Spring, pp. 209. https://doi.org/10.7289/V5NZ85MT.

Bradford, M.M., 1976. A rapid and sensitive method for the quantitation of microgram 
quantities of protein utilizing the principle of protein-dye binding. Anal. Biochem. 72, 248-254. https://doi.org/10.1016/0003-2697(76)90527-3.

Chabot, D., 2016. fishMO2: Calculate and plot the standard metabolic rate (SMR), the critical oxygen level (O2crit) and the specific dynamic action (SDA) and related variables in fishes and crustaceans.

Chabot, D., Steffensen, J.F., Farrell, A.P., 2016. The determination of standard metabolic rate in fishes. J. Fish Biol. 88, 81-121. https://doi.org/10.1111/jfb.12845.

Claisse, J.T., Pondella, D.J., Love, M., Zahn, L.A., Williams, C.M., Williams, J.P., Bull, A.S., 2014. Oil platforms off California are among the most productive marine fish habitats globally. Proc. Natl. Acad. Sci. U. S. A. 111, 15462-15467. https://doi.org/ 10.1073/pnas.1411477111.

Clarke, A., 1991. What is cold adaptation and how should we measure it? Amer. Zool. 31, 81-92.

de la Cruz-Francisco, V., González-González, M., Morales-Quijano, I., 2015. Extension of the geographical range of the alien species: Neopomacentrus cyanomos (Bleeker, 1856) (Perciformes-Pomacentridae) in the Lobos-Tuxpan Reef System, Veracruz, Mexico. Revista Investigaciones Marinas 35, 101-108. uri. hdl.handle.net/1834/9079.

Dimitriadis, V.K., Gougoula, C., Anestis, A., Pörtner, H.O., Michaelidis, B., 2012. Monitoring the biochemical and cellular responses of marine bivalves during thermal stress by using biomarkers. Mar. Environ. Res. 73, 70-77. https://doi.org/10.1016/j. marenvres.2011.11.004.

Dukan, S., Farewell, A., Ballesteros, M., Taddei, F., Radman, M., Nyström, T., 2000. Protein oxidation in response to increased transcriptional or translational errors. Proc. Natl. Acad. Sci. U. S. A. 97, 5746-5749. https://doi.org/10.1073/pnas 100422497.

Ellman, G.L., Courtney, D., Andres, V., Featherstone, R.M., 1961. A new and rapid colorimetric determination of acetylcholinesterase activity. Biochem. Pharmacol. 7 88-95. https://doi.org/10.1016/0006-2952(61)90145-9.

Ferreira, N.G.C., Morgado, R., Santos, M.J.G., Soares, A.M.V.M., Loureiro, S., 2015. Biomarkers and energy reserves in the isopod Porcellionides pruinosus: the effects of long-term exposure to dimethoate. Sci. Total Environ. 502, 91-102. https://doi.org/ 10.1016/j.scitotenv.2014.08.062.

Freitas, C., Olsen, E.M., Moland, E., Ciannelli, L., Knutsen, H., 2015. Behavioral responses of Atlantic cod to sea temperature changes. Ecol. Evol. 5, 2070-2083. https://doi. org/10.1002/ece3.1496.

Friedlander, A.M., Ballesteros, E., Fay, M., Sala, E., 2014. Marine communities on oil platforms in Gabon, West Africa: high biodiversity oases in a low biodiversity environment. PLoS One 9, e103709-e103715. https://doi.org/10.1371/journal.pone. 0103709.

Gericke, R.L., Heck, K.L.Jr, Fodrie, F.J., 2014. Interactions between northern-shifting tropical species and native species in the northern Gulf of Mexico. Estuaries Coast. 37, 952-961. https://doi.org/10.1007/s12237-013-9733-x.

Giraudoux, P., 2018. pgirmess: Spatial Analysis and Data Mining for Field Ecologists. In: R package version 1.6.9.

González-Gándara, C., de la Cruz-Francisco, V., 2014. Unusual record of the Indo-Pacific pomacentrid Neopomacentrus cyanomos (Bleeker, 1856) on coral reefs of the Gulf of Mexico. Bioinvasions Rec 3, 49-52. https://doi.org/10.3391/bir.2014.3.1.09.

Goth, L.A., 1991. Simple method for determination of serum catalase activity and revision of reference range. Clin. Chim. Acta 196, 143-152.

Habary, A., Johansen, J.L., Nay, T.J., Steffensen, J.F., Rummer, J.L., 2017. Adapt, move or die - how will tropical coral reef fishes cope with ocean warming? Glob. Change Biol. 23, 566-577. https://doi.org/10.1111/gcb.13488.

Habig, W.H., Jakoby, H.B., 1981. Glutathione S-Tranferases (rat and human). In: Jakoby, W.B. (Ed.), Methods in Enzymology. 77. Academic Press, London, pp. 218-235 Detoxication and drug metabolism: Conjugation and related systems.

Hadwan, M.A., Abed, H.N., 2016. Data supporting the spectrophotometric method for the estimation of catalase activity. Data in Brief. 6, 194-199. https://doi.org/10.1016/j. dib.2015.12.012.

Hastings, R.W., Ogren, L.H., Mabry, M.T., 1976. Observations of fish fauna associated with offshore platforms in the northeastern Gulf of Mexico. Fish. Bull. 74, 387-402.

He, J., Qiang, J., Yang, H., Xu, P., Zhu, Z.X., Yang, R.Q., 2015. Changes in the fatty acid composition and regulation of antioxidant enzymes and physiology of juvenile genetically improved farmed tilapia Oreochromis niloticus (L.), subjected to short-term low temperature stress. J. Therm. Biol. 53, 90-97. https://doi.org/10.1016/j. jtherbio.2015.08.010.

Hosokawa, M., Satoh, T., 2001. Measurement of carboxylesterase (CES) activities. In: Current protocols in toxicology. John Wiley \& Sons, Inc, In. https://doi.org/10.1002/ 0471140856.tx0407s10.

Hsu, C.Y., Chiu, Y.C., 2009. Ambient temperature influences aging in an annual fish (Nothobranchius rachovii). Aging Cell 8, 726-737. https://doi.org/10.1111/j.14749726.2009.00525.x.

Isasa, M., Suñer, C., Díaz, M., Puig-Sàrries, P., Zuin, A., Bichman, A., Gygi, S.P., Rebollo, E., Crosas, B., 2016. Cold temperature induces the reprogramming of proteolytic pathways in yeast. J. Biol. Chem. 291, 1664-1675. https://doi.org/10.1074/jbc. M115.698662.

James, D., Hornik, K., 2016. Chron: chronological objects which can handle dates and times. R package version 2, 3-48.

Johansen, J.L., Jones, G.P., 2011. Increasing ocean temperature reduces the metabolic performance and swimming ability of coral reef damselfishes. Glob. Change Biol. 17, 2971-2979. https://doi.org/10.1111/j.1365-2486.2011.02436.x.

Johansen, J.L., Steffensen, J.F., Jones, G.P., 2015. Winter temperatures decrease swimming performance and limit distributions of tropical damselfishes. Conserv. Physiol. 3, 1-12. https://doi.org/10.1093/conphys/cov039.

Johnston, M.W., Akins, J.L., 2016. The non-native royal damsel (Neopomacentrus cyanomos) in the southern Gulf of Mexico: an invasion risk? Mar. Biol. 163, 1-14. https://doi.org/10.1007/s00227-015-2777-7.
Lamarre, S.G., Blier, P.U., Driedzic, W.R., Le François, N.R., 2010. White muscle 20S proteasome activity is negatively correlated to growth rate at low temperature in the spotted wolffish Anarhichas minor. J. Fish Biol. 76, 1565-1575. https://doi.org/10. 1111/j.1095-8649.2010.02581.x.

Lennox, R., Choi, K., Harrison, P.M., Paterson, J.E., Peat, T.B., Ward, T.D., Cooke, S.J., 2015. Improving science-based invasive species management with physiological knowledge, concepts, and tools. Biol. Inv. 17, 2213-2227. https://doi.org/10.1007/ s10530-015-0884-5.

Li, C., Qin, L., Qu, R., Sun, P., Wang, Z., 2016. Responses of antioxidant defense system to polyfluorinated dibenzo-p-dioxins (PFDDs) exposure in liver of freshwater fish Carassius auratus. Ecotox. Environ. Safe. 126, 170-176. https://doi.org/10.1016/j ecoenv.2015.12.036.

Lyons, T.J., Tuckett, Q.M., Hill, J.E., 2019. Data quality and quantity for invasive species: a case study of the lionfishes. Fish Fish. 88, 305-312. https://doi.org/10.1111/faf. 12374.

Madeira, C., Madeira, D., Diniz, M.S., Cabral, H.N., Vinagre, C., 2016. Thermal acclimation in clownfish: an integrated biomarker response and multi-tissue experimental approach. Ecol. Indic. 71, 280-292. https://doi.org/10.1016/j.ecolind.2016.07.009.

Madeira, C., Mendonça, V., Leal, M.C., Flores, A.A.V., Cabral, H.N., Diniz, M.S., Vinagre, C., 2018. Environmental health assessment of warming coastal ecosystems in the tropics - application of integrative physiological indices. Sci. Total Environ. 643, 1-12. https://doi.org/10.1016/j.scitotenv.2018.06.152.

Madeira, D., Mendonça, V., Madeira, C., Gaiteiro, C., Vinagre, C., Diniz, M.S., 2019. Molecular assessment of wild populations in the marine realm: importance of taxonomic, seasonal and habitat patterns in environmental monitoring. Sci. Total Environ. 654, 1-14. https://doi.org/10.1016/j.scitotenv.2018.11.064.

Marigómez, I., Garmendia, L., Soto, M., Orbea, A., Izagirre, U., Cajaraville, M.P., 2013. Marine ecosystem health status assessment through integrative biomarker indices: a comparative study after the Prestige oil spill "Mussel Watch". Ecotoxicol. 22, 486-505. https://doi.org/10.1007/s10646-013-1042-4.

Mesquita, C.S., Oliveira, R., Bento, F., Geraldo, D., Rodrigues, J.V., Marcos, J.C., 2014. Simplified 2,4-dinitrophenylhydrazine spectrophotometric assay for quantification of carbonyls in oxidized proteins. Anal. Biochem. 458, 69-71. https://doi.org/10.1016/ j.ab.2014.04.034.

Nakazawa, M., 2018. fmsb: Functions for Medical Statistics Book with some Demographic Data. In: R package version 0.6.3.

Nilsson, G.E., Crawley, N., Lunde, I.G., Munday, P.L., 2009. Elevated temperature reduces the respiratory scope of coral reef fishes. Glob. Change Biol. 15, 1405-1412. https:// doi.org/10.1111/j.1365-2486.2008.01767.x.

Norin, T., Malte, H., Clark, T.D., 2014. Aerobic scope does not predict the performance of a tropical eurythermal fish at elevated temperatures. J. Exp. Biol. 217, 244-251. https://doi.org/10.1242/jeb.089755.

O'Brien, K.M., 2011. Mitochondrial biogenesis in cold-bodied fishes. J. Exp. Biol. 214, 275-285. https://doi.org/10.1242/jeb.046854.

Oksanen, J., Blanchet, F.G., Friendly, M., Kindt, R., Legendre, P., McGlinn, D., Minchin, P.R., O’Hara, R.B., Simpson, G.L., Solymos, P., Stevens, M.H.H., Szoecs, E., Wagner, H., 2019. vegan: Community Ecology Package. R package version 2, 4-284.

Pajuelo, J.G., González, J.A., Triay-Portella, R., Martín, J.A., Ruiz-Díaz, R., Lorenzo, J.M., Luque, Á., 2016. Introduction of non-native marine fish species to the Canary Islands waters through oil platforms as vectors. J. Marine Syst. 163, 23-30. https://doi.org/ 10.1016/j.jmarsys.2016.06.008.

Park, J.Y., Han, K.H., Cho, J.K., Kim, K.M., 2016. Survival rate and hematological responses with temperature changes of red spotted grouper, Epinephelus akaara in South Korea. Dev. Reprod. 20, 103-112. https://doi.org/10.12717/DR.2016.20.2.103.

Pierce, D., 2015. ncdf4: Interface to Unidata netCDF (Version 4 or Earlier) Format Data Files. In: R package version 1.15.

Poloczanska, E.S., Burrows, M.T., Brown, C.J., García Molinos, J., Halpern, B.S., HoeghGuldberg, O., Kappel, C.V., Moore, P.J., Richardson, A.J., Schoeman, D.S., Sydeman, W.J., 2016. Responses of Marine Organisms to Climate Change across Oceans. Front. Mar. Sci. 3, 1-21. https://doi.org/10.3389/fmars.2016.00062.

Pörtner, H.O., 2010. Oxygen- and capacity-limitation of thermal tolerance: a matrix for integrating climate-related stressor effects in marine ecosystems. J. Exp. Biol. 213, 881-893. https://doi.org/10.1242/jeb.037523.

Pörtner, H.O., Knust, R., 2007. Climate change affects marine fishes through the oxygen limitation of thermal tolerance. Science. 315, 95-97. https://doi.org/10.1126/ science. 1135471.

Precht, H., 1958. Concepts of the temperature adaptation of unchanging reaction systems of cold-blooded vertebrates. In: Prosser, C.L. (Ed.), Physiological Adaptation. Ronald Press, New York.

R Core Team, 2018. R: A Language and Environment for Statistical Computing. R Foundation for Statistical Computing, Vienna, Austria. www.R-project.org.

Robertson, D.R., Kingon, K., 2019. The alien Indo-Pacific damselfish, Neopomacentrus cyanomos, at Trinidad. Zenodo. https://doi.org/10.5281/zenodo.3364568.

Robertson, D.R., Perez-España, H., Nuñez Lara, E., Puc Itza, F., Simões, N., 2016. The fishes of Cayo Arcas (Campeche Bank, Gulf of Mexico): an updated checklist. ZooKeys. 640, 139-155. https://doi.org/10.3897/zookeys.640.10862.

Robertson, D.R., Dominguez-Dominguez, O., Victor, B., Simões, N., 2018. An indo-Pacific damselfish (Neopomacentrus cyanomos) in the Gulf of Mexico: origin and mode of introduction. PeerJ. 6, e4328. https://doi.org/10.7717/peerj.4328.

Rodgers, G.G., Donelson, J.M., McCormick, M.I., Munday, P.L., 2018. In hot water: sustained ocean warming reduces survival of a low-latitude coral reef fish. Mar. Biol. 165, 1-10. https://doi.org/10.1007/s00227-018-3333-z.

Rodríguez-Fuentes, G., Armstrong, J., Schlenk, D., 2008. Characterization of muscle cholinesterases from two demersal flatfish collected near a municipal wastewater outfall in Southern California. Ecotox. Environ. Safe. 69, 466-471. https://doi.org/ 10.1016/j.ecoenv.2007.06.008. 
Rosas, C., Tut, J., Baeza, J., Sánchez, A., Sosa, V., Pascual, C., Arena, L., Domingues, P., Cuzon, G., 2008. Effect of type of binder on growth, digestibility, and energetic balance of Octopus maya. Aquaculture. 275, 291-297. https://doi.org/10.1016/j aquaculture.2008.01.015.

Ross, M.K., Streit, T.M., Herring, K.L., Xie, S., 2010. Carboxylesterases: dual roles in lipid and pesticide metabolism. J. Pestic. Sci. 35, 257-264. https://doi.org/10.1584/ jpestics.R10-07.

Rummer, J.L., Couturier, C.S., Stecyk, J.A.W., Gardiner, N.M., Kinch, J.P., Nilsson, G.E., Munday, P.L., 2014. Life on the edge: thermal optima for aerobic scope of equatorial reef fishes are close to current day temperatures. Global Change Bio. 20, 1055-1066. https://doi.org/10.1111/gcb.12455.

Sarkar, D., 2008. Lattice: Multivariate Data Visualization with R. Springer, New York ISBN 978-0-387-75968-5.

Schofield, P.J., Neilson, M.E., 2019. Neopomacentrus cyanomos (Bleeker, 1856) Factsheet. US Geological Survey, Nonindigenous Aquatic Species Database, Gainesville, FL. http://nas.er.usgs.gov/ queries/ FactSheet.aspx?SpeciesID = 2936 (Revision date: April 26, 2019).

Setu, S.K., Ajith Kumar, T.T., Blasubramanian, T., Dabbagh, A.R., Keshavarz, M., 2010. Breeding and rearing of regal damselfish Neopomacentrus cyanomos (Bleeker, 1856): the role of green water in larval survival. World J. Fish Mar. Sci. 2, 551-557.

Sidell, B.D., Driedzic, W.R., Stowe, D.B., Johnston, I.A., 1987. Biochemical correlations of power development and metabolic fuel preferenda in fish hearts. Physiol. Zool. 60, 221-232.

Simões, N., Robertson, D.R., 2016. An indo-Pacific damselfish on an oil-platform in the
Southwest Gulf of Mexico. Zenodo. https://doi.org/10.5281/zenodo.58455.

Sokolova, I.M., Frederich, M., Bagwe, R., Lannig, G., Sukhotin, A.A., 2012. Energy homeostasis as an integrative tool for assessing limits of environmental stress tolerance in aquatic invertebrates. Mar. Environ. Res. 79, 1-15. https://doi.org/10.1016/ j.marenvres.2012.04.003.

Steffensen, J.F., 1989. Some errors in respirometry of aquatic breathers: how to avoid and correct for them. Fish Physiol. Biochem. 6, 49-59. https://doi.org/10.1007/ BF02995809.

Stoot, L.J., Cairns, N.A., Cull, F., Taylor, J.J., Jeffrey, J.D., Morin, F., Mandelman, J.W., Clark, T.D., Cooke, S.J., 2014. Use of portable blood physiology point-of-care devices for basic and applied research on vertebrates: a review. Conserv. Physiol. 2, 1-21. https://doi.org/10.1093/conphys/cou011.

Svendsen, M.B.S., Bushnell, P.G., Christensen, E.A.F., Steffensen, J.F., 2016. Sources of variation in oxygen consumption of aquatic animals demonstrated by simulated constant oxygen consumption and respirometers of different sizes. J. Fish Biol. 88, 51-64. https://doi.org/10.1111/jfb.12851.

Tennekes, M., 2017. tmap: Thematic maps. In: R package version 1.10.

Torquato, F., Jensen, H.M., Range, P., Bach, S.S., Ben-Hamadou, R., Sigsgaard, E.E., Thomsen, M.F., Møller, P.R., Riera, R., 2017. Vertical zonation and functional diversity of fish assemblages revealed by ROV videos at oil platforms in the Gulf. J. Fish Biol. 91, 947-967. https://doi.org/10.1111/jfb.13394.

Umminger, B.L., 1970. Physiological studies on supercooled killifish (Fundulus heteroclitus). III. Carbohydrate metabolism and survival at subzero temperatures. J. Exp. Zool. 173, 159-174. https://doi.org/10.1002/jez.1401730205. 